\title{
The Great Plains Experience: University of Mid-America Edu- cational Program
}

\section{by Emilia Nordvet}

To the Cheyenne, Lakota, Comanche and other Indian tribes who lived there, the Great Plains region was the provider of life. They lived off the herds of buffalo, deer, antelope and other game that the plains provided in abundance. When the herds moved to new grazing lands, the people moved, too. To survive on the Great Plains, these Indians had adopted a nomadic way of life.

But the Great Plains was seen through different eyes by the first white settlers who crossed the Missouri River and headed west. Appearing incompatible with their agricultural way of life, the plains seemed to deserve its reputation as "The Great American Desert." Yet by the end of the Civil War, an opposite but equally exaggerated description of the region-"The Garden of the World"-was becoming popular.

In reality, the Great Plains was neither desert nor garden, of course. To the farmer, however, it was a harsh, fickle environment that could yield a bumper crop one year and nothing but wind, dust and grasshoppers the next two or three.

Where the nomadic Plains Indians had thrived, the American settler at first found tough going. Some died trying to tame the land. Many others gave up and returned to the east where climate and soil were more conducive to their way of farming. But some stayed. And gradually, as their technology advanced, these settlers were able to adapt their Euro-American culture to life on the Great Plains. If not the "Garden of the World," then at least the Great Plains became the breadbasket of the growing nation.

The human experience in the Great Plains region over the last several hundred years (up to and including the present) is surveyed and interpreted in a multi-media college level course produced in 1976-78 by the University of Mid-America in Lincoln, Nebraska. UMA is a consortium of eleven midwestern universities, funded principally by the National Institute of Education. "The Great Plains Experience" focuses on how people have adapted to life on the plains region, which stretches from the Rocky Mountains as far east as the Missouri River valley, and southward from the Prairie Provinces of Canada to the Texas Panhandle. The course introduces students to the cultural history of the region through a study of political, social and economic developments which promoted settlement of the plains. History comes alive through the poignant first-hand accounts of Plains Indian Luther Standing Bear, working cowboy Andy Adams, early settler Flora Hunter, and the letters and paintings of George Catlin that date to the early nineteenth century.

The course begins with a geological introduction to the land, progresses through the settlement of the region and concludes with a study of contemporary culture: what life is like on the Great Plains today-cattle grazing on 
great stretches of unplowed grasslands; immense wheat fields separating towns and cities dependent on agribusiness for their existence; important repositories of fossil fuels; and the ever-present threat of drought, hail and blizzard.

The course was created under the leadership of an instructional designer, working with a number of historical scholars and TV production specialists. The primary academic creator and senior historian of the course was James E. Wright, Dartmouth College. Field testing of the course components has shown that learner interest is high.

Materials from history, literature, geography, art, anthropology and sociology are integrated into the course. Themes that go beyond geographic boundaries are principles of how people adapt to their environment, the interaction of environment and culture, and change and persistence among cultural groups.

Two of the six television programs produced for this course by the University of Mid-America have received national recognition. Pulitzer Prize winners narrate each of the first two television programs. Novelist-historian Wallace Stegner provides the introduction to the region in "The Land," and N. Scott Momaday, poet, novelist and professor of literature, tells the story "The Lakota: One Nation of The Plains." The programs were shot on location and include many interviews and portraits of the land and people.

The materials produced for the course include the six half-hour television programs, a study guide to facilitate home study or independent study, a 450-page collection of readings, twelve newspaper-style feature articles, and viewing notes to the television programs. Students also read The Southern Cheyennes by Donald J. Berthrong (University of Oklahoma Press) and Old Jules by Mari Sandoz (University of Nebraska Press.)

Several Iowa higher education institutions may offer the course for credit (including Iowa State University and the University of Iowa, which are members of the UMA consortium) as the television progams are broadcast over the Iowa Public Broadcasting Network and WOI-TV beginning February 12, 1979. Other institutions may use one or more of the course components to enrich existing oncampus courses.

For additional information, contact Emilia Nordvet, 111AI Curtiss Hall, ISU, Ames, Iowa 50011. 
Copyright of Annals of Iowa is the property of State of Iowa, by \& through the State Historical Society of Iowa and its content may not be copied or emailed to multiple sites or posted to a listserv without the copyright holder's express written permission. However, users may print, download, or email articles for individual use. 